\title{
TRASH TO TREASURE: UTILIZING WASTE MATERIALS AS A MEDIUM OF ENGLISH INSTRUCTION
}

\author{
Sondang Pondan Perlindungan Leoanak \\ Politeknik Pertanian Negeri Kupang \\ sonleo2002@yahoo.com \\ Bonik Kurniati Amalo \\ Politeknik Pertanian Negeri Kupang \\ amalokurniati@yahoo.co.id
}

\begin{abstract}
Absstract : It is believed that teaching and learning experiences that involve the learner actively in practical examples are engaged longer than theoretical experiences. Instructional resources are teaching aids or media used to help teachers and students in classroom interaction. These aids help teachers to provide fun, interesting and enjoyable platform to convey information of a given topic as a means of motivating students to achieve their learning objectives. The present study aims to find out how the teachers in Rijalul Ghad Islamic school in Kera island, Kupang regency, East Nusa Tenggara Province, Indonesia utilized waste materials to support their teaching and learning process in the classroom. The data were collected using classroom observation, semi-structured interview with the teachers as well as the students and a list of 15-item questions about the level of application of instructional media in the classroom addressed to the teachers and the students. This study reveals that the students were active during the application of the instructional media using waste materials such as papers and drinking mineral bottles. In addition, during the application of the teaching and learning aids, the students also learnt how to work in team during group discussion and how to appreciate other's opinion. However, a support on the use of teaching aids, especially teacher's made (or teacher-students' made) need to be increased among teachers. This is because, not all teachers are able to utilize waste materials in to instructional media.
\end{abstract}

Keywords: utilizing, waste materials, instructional resources

\section{BACKGROUND}

Waste definitions may vary in different countries (i.e. developed and developing countries). For instance, in developed countries, the elimination of used electronic devices, furniture, used papers and used bottles, etc. incurs cost of disposal and are defined as waste. In developing countries, these are regarded as favorable goods and could still be used after being repaired (Damahuri, 2010).

As a developing country, Indonesia also has waste disposal issues, especially in urban region. It was reported that $60 \%-70 \%$ of Municipal Solid Waste (MSW) in Indonesia is able be transported to final disposal by the City/ District Cleanliness Department. The rest would be handled by the community through their self-effort or spread and systematically disposed all over the city the recycling economic actors (Damahuri, 2005). In accordance to this issue, Kupang city, the capital region of East Nusa 
Tenggara Province, Indonesia also face the same problem. The increasing of MSW in this city is due to variety of reasons like population growth, public awareness of green and clean environment, etc.

One of the mission of Kupang government is to make an efficient and effective urban spatial supported by good infrastructures and sustainable environment. To achieve such goals, the program of clean water management and high-quality neighborhood sanitation are developed under the name "Kupang Green and Clean" (KGC). This program was first introduced about a decade ago. This program aims is to increase the environment quality of the city. All the citizen is encouraging to support the program including school citizen. Students, teachers and school staff are also asked to participate in the program such as to collect and dispose waste material properly. This program has become one of the references for almost all the cities in the province to increase green and healthy environment.

This program has become a challenge for the teacher in the city to utilize waste material as instructional resources in teaching and learning process in the classroom. It is believed that the use of waste material as instructional resources in teaching and learning process will create more practical lessons and also will increase students' participation and interaction in the classroom. Furthermore, educators believed that teaching and learning experiences that involve the learner actively in practical examples (i.e. the use of instructional resources) are engaged longer than theoretical experiences (Yeboah, Asante \&Asare, 2016).

Many scholars have emphasized the importance on the application of instructional materials in classroom interaction as to achieve better performance of students in their academics (Nwike\& Catherine, 2013, Tuimur \& Chemwei, 2015; Okobia, 2011; Arum, 2015). Many other scholars have also proved that there is a significance correspondence of using instructional media with effective teaching and learning process (Makewa et al., 2012). For Naz and Akbar (2010), instructional media have many benefits in terms of repeatability, transportability and increased equity access. They argue that instructional media help teachers to convey teaching and learning materials effectively as they assist students in greater acquisition of learning materials. In addition, instructional media may also help to draw students' attention in the classroom learning process (Reeves, 1998).

The present study aims to bring up the issue on one of the factors in choosing instructional media, which is based on Gagne, Briggs \& Wager's (1992) factors contributing to the media selection. In general, the study aims to find out how the teachers in Rijalul Ghad Islamic school in Kera island, Kupang regency, East Nusa Tenggara Province, Indonesia utilized waste materials to support their teaching and learning process of English in the classroom. A previous study has been done in the school (Leoanak\&Amalo, 2018b) and it is found that the teacher's behavior contributing students' positive motivation practice in the classroom. One of the teacher's behaviors applied is by using teaching aids in teaching and learning process in the class room. Hence, in a narrow scope, the present study aims to find out how the teachers in the school use waste materials which are cheap and low cost but reliable to his teaching materials to be taught in the classroom.

Many studies have revealed that there are many factors that give positive contribution in the success of teaching English in for non-native speakers. Some of them 
are by using code switching (Leoanak \& Amalo, 2018a; Hamre \& Pianta, 2001), positive motivation (Leoanak \& Amalo, 2018b; Brok, et al, 2005) and instructional media (Kochhar, 2004; Newby, 2000; Nicola \& Nicola, 1997).

\section{Instructional Resources}

Instructional resources are physical teaching aids used to help teachers and students in classroom teaching and learning process. These aids help teachers to provide interesting platform (effective presentation) to convey information of a given topic, since they motivate learners to learn more. The use of classroom instructional aids or materials does not only help teachers and students to work collaboratively but also results in more cooperative learning activities among the students (Okobia, 2011). By classroom instructional aids, concepts and abstracts or ideas will be easily transferred as they act as supporting elements in classroom interactions (Yildirim, 2008).

The application of instructional materials in classroom interaction is to promote learning effectively i.e. by improving the quality of teaching and learning (Okobia, 2011). To make learning more effective, instructional materials are used to simplify teachers' teaching performance. These instructional materials are vital for educational inputs and they bring life to learning by gripping students' attention in the learning process. The use of instructional materials in the classroom interaction helps the teacher to explain new concepts clearly, resulting in better students' comprehension of the learning materials being taught (Tuimur\&Chemwei, 2015).

The use of instructional materials in the classroom interaction also stimulates students' senses on the learning materials. It is argued that students learn better through sight (eyes) and hearing (ears) compared to other senses such as taste or touch (Sampath, 1990). While in relation to memorizing things, say and do are better than see and hear. Sampath (1990) further explains that, students will have better memories on learning materials when they learn by said and done (80\%) compared to see and hear (50\%). Other senses would be read (10\%), hear (20\%) and see (30\%).

The work of Sampath (1990) implies that for more learning experiences to be internalized and achieved, more of the students' senses have to be stimulated. Various senses of the students need to be stimulating at once such as practicing (saying and doing) rather than theorizing (reading) alone. The stimulation can be done by asking the students to make and describe a project using waste materials found in their surroundings. Or, teachers and students can utilize waste materials in creating instructional media or materials for classroom teaching and learning activities.

\section{Instructional Resources Categorization}

Instructional materials can be categorized on the basis of the way to apply: real objects, modern (i.e. computer, TV) and traditional such as chalkboard (Omenge\&Priscah, 2016; Olawale, 2013; Manjale\& Abel, 2012; Alobo, 2010; Azikiwe, 2007; Mustapha et al., 2002; Chandra, Shah \& Joshi, 1998; Kemp \&Daylon, 1998; Mehra, 1992).

Omenge\& Priscah (2016) classify instructional media as all the materials and substantial resources that teachers might draw on to implement their teaching instruction as well as to facilitate students' achievement of instructional objectives. They mention instructional media as chalkboards, printed material (books, worksheets, etc.), display 
boards, charts, slides, overheads, real objects, and videotape or film, computers, real objects or models, DVDs, CD-ROMs, the Internet, and interactive video conferencing etc.

Olawale (2013) classifies instructional media in to three forms: sound (audio), sight (visual) and combination of sound and sight (audio-visual). Furthermore, he subcategorizes audio form as radio, record players cassettes gramophone, CDs, etc. He groups visual aid as maps, film steps, specimen, pictures, charts, Blackboard, posters etc. The third form is audio-visual where he sets Television films, DVDs, projector, etc. in to this form.

Three models of instructional media have also been proposed by Manjale \& Abel (2012). The three models of instructional media are: visual (content is received through the sense of Sight, e.g. books, posters, pictures and the like), audio (content involves hearing such as radio, tapes, telephone, disc recordings) and audio - visual (such as films, television, demonstrations and motion pictures).

Naz \& Akbar (2010) summarize instructional media in to some groups, they are: print media (i.e. Newspaper, magazines, digest, journals, poster etc.), graphic media (i.e. graphs models, maps, etc.), photographic media (still pictures, motion pictures, etc.), audio media (i.e. audiotape, radio, etc.), Television/video (i.e. videotape, VCD, etc.), computers, simulations and games (i.e. boards, human, etc.). For them, instructional media are used to engage learners in the learning process.

According to Mustapha et al. (2002) and Azikiwe (2007) as cited in Alobo (2010),instructional media are classified as visual aids, audio-visual aids, audio aids and resources (human and materials). They state that instructional media are devices that appeal to the sense of sight and touch as well as sense of smell. These media consist of non-projected aids (chalkboard and adhesives), pictorial aids (charts and pictures), mobile, three-dimensional aids, projected aids which include film-strips and slides, and slides projector, laboratory equipment, chemical and apparatus and books.

\section{Principles of Instructional Resources Selection}

In choosing the types of instructional media to be applied in the teaching and learning process in the classroom, reliability, relevance and cost should be considered by a teacher (Olawale, 2013). Furthermore, Olawale (2013) explains that reliability means a selected material is used to obtain lesson objectives. In relation to the relevance, he points out that a selective choice and caution must be carried out to guarantee that only related instructional materials are used while teaching. Concerning cost, Olawale (2013) defines cost as the following: the instructional materials chosen should be in the range of teacher's sponsorship (within the teacher's reach). In accordance to this, he lists some guiding factors for teachers in selecting instructional materials, they are:

a. Availability where the teacher should ensure that the instructional materials to be used are available when needed on the date of use. This means that the materials should be in the teacher's hands on the date they are needed. It does not matter, whether they are taken from the store or they are teacher's made, they should be tested before the day of the lesson.

b. Accessibility. It is the duty of the teacher to ensure that the materials to be used as instructional materials are not only available but also accessible to him. If they are already made materials they should be within reach of the teacher (at the teacher's hands) on the date and time of use. 
c. Affordability. The instructional materials to be used should not be expensive. The cost should be such that either the teacher or the school can afford.

d. The teacher who is using the instructional materials should concern about the appropriateness of the materials for his intended learners. The materials should be suitable for the students in relation to their age group, needs, experience and intelligence.

e. The instructional materials to be used should be easy to control or operate (e.g. no technical problem for electronic instructional materials).

f. The instructional materials selected for teaching by the teacher should have a good quality.

g. The instructional materials should be the recent ones and should not be out of date. This means that, the instructional materials should portray original, innovative and creative thought.

Naz\&Akbar (2010) points out that a teacher can make more effective use of media if he/she understands the underlying concepts about teaching-learning process. One of them is by having highly structure instructional media. Hence, they propose some principles when choosing instructional media where students' can actively involve and more interactive teaching process can be gained. The principles are:

a. Selected material should have appropriate attributes.

b. Students' lesson materials should be connected to their prior learning and indicating its' relationship to present objectives.

c. Students' lesson material should be presented under the best possible environmental conditions.

d. Learning experiences feedback should be getting from students.

e. Internal impact should be evaluated.

Alobo (2010) also proposes four fundamental guidelines in the selection of instructional media. The guidelines are described as follows:

a. It is connected to the topic of the lesson to be taught.

b. It should within the age and maturational of students' level.

c. It must be pre-viewed by the teacher before taking into the actual teaching and learning activities.

d. The instructional media should be accurate in content and acceptable in other places for same lessons.

Azikiwe (2007) identifies several standard or criteria when choosing resource materials or media, they are:

a. Availability of the needed materials (resource materials are available as well as accessible to the teachers and the learners. 
b. The instructional media to be selected must be relevant to the lesson objectives. This is because the objectives that the materials are designed to achieve should be in accordance to those that the teacher and the learners are trying to achieve.

c. Any selected learning materials resources must be suitable to the learning outcomes as well as to the students.

d. Physical features such as attractiveness, durability, size and clarity of the learning resources should be considered. Other features that need to be considered are: accuracy, clarity and usefulness (of the illustrations, drawings and paintings) and weight of the materials for ease of handling and storage.

e. The instructional materials should be cheap (time and energy) and economical (without sacrificing its' quality). This can be done by utilizing waste materials or considering the available local materials.

Gagne, Briggs \& Wager (1992) say that instructors who deliver instruction often select and use a great variety of both print and non-print media in their teaching and learning activities. They add that in practical instructional situations, the media employed are often chosen on grounds of availability, feasibility, and cost. Obviously, these are important factors and must be considered in the final selection. From this point, they propose some factors contributing to the media selection, they are:

a. Physical attributes of the media in which physical characteristics of the communications they are able to display. For example, some media permit visual displays (e.g. TV, DVDs movies, etc.), while some others are presenting verbal displays, either as printed text (e.g. photos, posters, etc.) or as audio messages (radio, audio CDs, etc.).

b. Task characteristics mean that when choosing instructional media of teaching and learning interaction, the learning outcomes needs to be carefully considered.

c. Learner characteristics or variables deal with selecting media in which under the contemplation of students' characteristics.

d. Learning and school environments that need to be considered are: school budget, size of class, capability for developing new materials, availability of media equipment, teacher capabilities and availability for an instructional design effort, availability of modular materials for individualized, performance-based instruction, attitudes of principal and teachers toward innovations and school architecture.

e. Environmental support such as support from other school staff and educators (team management system).

f. The economy and the culture support such as electric power to electronic media (TV or radio). All these factors should be considered if the media selected for a delivery system are to find acceptance. 


\section{METHOD}

\section{Participants}

There were 15 students and 2 teachers of RijalulGhad Islamic School took part in as the participants of the study.

\section{Instruments}

In obtaining the required data, three types of data collection procedure had been conducted. The data collection procedures were: classroom observation, questionnaire and semi-structured interview.

During classroom observation, the writers observed how the teachers utilize waste materials as their teaching aids in the classroom. The guidelines for the observation stage were compiled based on classification of instructional media proposed byOmenge \& Priscah (2016), Olawale (2013), Manjale\& Abel (2012) and Naz\&Akbar (2010).In this stage, the writers noted down how the teaching aids were compiled (i.e. teachers' made or teacher-students' collaboration). The writers also observed how the connection between the teaching aids and the learning outcomes or the lesson objectives being taught. And then, the writers alsonoted down how the material of instructional media were made of (i.e. plastic, glass, wood, rubber, paper, bottles, can, etc.). And finally, the writers noted the implication on the use of the teaching aids to students' learning performance.

All the notes during observation stage were used to carry semi-structure interview data collection type. This was done to get a brief description about the way the teachers utilize waste materials as their teaching aids in the classroom, the connection between the teaching aids and the learning outcomes, the material used and the implication of the used media to the students' learning outcomes. The guidelines for semi-structure interview questions were based on Naz\& Akbar (2010), Alobo (2010), Azikiwe (2007) and Gagne, Briggs \& Wager's (1992) principles of media selection.

The questions consisted of two main sections. The first section was about respondents' personal information and the rest was about teachers' way to utilize waste materials as a medium of their teaching and learning aids. In the second section of the questionnaire, the respondents were asked to give information to a 15 -item of level of application of teaching aids in the classroom, starting from 'Always' at the top level down to 'Never' at the bottom level (Vagias, 2006) along with the comments and additional information and examples (if necessary).

\section{Data Analysis}

A qualitative research design has been applied in the present study. Qualitative research is concerned with developing explanations of social phenomena (Hancock, Ockleford \& Windridge, 2007). This type of research design is characterized by its aims, which relate to understanding some aspects of social life (Patton \& Cohran, 2007). The present study explains how the teachers in Rijalul Ghad Islamic school utilized waste materials in to an innovative and creative English teaching aids. The questions to be addressed in the present study are to find out the types of waste materials used, how the managing process happened, how to apply the teaching aids in their English teaching and learning activity and the impact to students' learning performance. 


\section{FINDINGS}

This paper is about how waste materials are utilized to create innovative and creative learning aids to support teacher - students' classroom interaction. This paper also examines the types of waste materials used in the making of those learning aids. Additionally, this paper also explains how those learning aids affect students' learning performance.

Based on the observation in the classroom, it is found that for some lesson topics, the instructional media were made available only by the teachers. While there were some instructional media made based on the collaboration between the teachers and the students. There was also a lesson topic in which the instructional media were taken from a ready used one (posters bought from the store). The instructional media applied were animate and inanimate types. Animate instructional type of media means that the teachers used living things in their teaching and learning classroom interaction. The examples of animate media applied by the teachers were: plants and human (the teacher themselves and the students). Concerning the type of inanimate instructional media, the teachers applied nonliving things for their teaching aids. The examples of these types of media applied by the teachers were: posters, mineral water bottles and papers.

The result of the 15-item of level of application of teaching aids in the classroom questionnaire is shown in the Table 1 below.

Table 1. The level of application of teaching aids in the classroom

\begin{tabular}{|c|c|c|c|c|c|c|}
\hline \multirow[b]{2}{*}{ No } & \multirow[b]{2}{*}{ Questions } & \multicolumn{5}{|c|}{ Level of Application } \\
\hline & & $\begin{array}{c}\text { Never } \\
(\%)\end{array}$ & $\begin{array}{c}\text { Rarely } \\
(\%)\end{array}$ & Sometimes (\%) & $\begin{array}{c}\text { Often } \\
(\%)\end{array}$ & Always (\%) \\
\hline 1 & $\begin{array}{l}\text { How often do you } \\
\text { make your own audio } \\
\text { lesson }\end{array}$ & 100 & 0 & 0 & 0 & 0 \\
\hline 2 & $\begin{array}{l}\text { How often do you } \\
\text { make your own } \\
\text { audio-visual aids }\end{array}$ & 100 & 0 & 0 & 0 & 0 \\
\hline 3 & $\begin{array}{l}\text { How often do you } \\
\text { make your own maps }\end{array}$ & 100 & 0 & 0 & 0 & 0 \\
\hline 4 & $\begin{array}{l}\text { How often do you } \\
\text { make your own } \\
\text { pictures }\end{array}$ & 0 & 0 & 52.94 & 47.06 & 0 \\
\hline 5 & $\begin{array}{l}\text { How often do you } \\
\text { make your own } \\
\text { charts }\end{array}$ & 0 & 0 & 70.59 & 29.41 & 0 \\
\hline 6 & $\begin{array}{l}\text { How often do you } \\
\text { make your own } \\
\text { poster }\end{array}$ & 0 & 0 & 64.71 & 35.29 & 0 \\
\hline 7 & $\begin{array}{l}\text { How often do you } \\
\text { make your own } \\
\text { worksheet }\end{array}$ & 0 & 0 & 47.06 & 52.94 & 0 \\
\hline 8 & $\begin{array}{l}\text { How often do you } \\
\text { make your own } \\
\text { computer } \\
\text { presentation }\end{array}$ & 100 & 0 & 0 & 0 & 0 \\
\hline 9 & How often do you & 29.41 & 35.29 & 35.29 & 0 & 0 \\
\hline
\end{tabular}




\begin{tabular}{|c|c|c|c|c|c|c|}
\hline & $\begin{array}{l}\text { make your own } \\
\text { boards game }\end{array}$ & & & & & \\
\hline 10 & $\begin{array}{l}\text { How often do you use } \\
\text { human as your } \\
\text { teaching aids }\end{array}$ & 0 & 0 & 70.59 & 29.41 & 0 \\
\hline 11 & $\begin{array}{l}\text { How often do you use } \\
\text { newspaper as your } \\
\text { teaching aids }\end{array}$ & 0 & 0 & 64.71 & 35.29 & 0 \\
\hline 12 & $\begin{array}{l}\text { How often do you use } \\
\text { magazine as your } \\
\text { teaching aids }\end{array}$ & 0 & 47.06 & 52.94 & 0 & 0 \\
\hline 13 & $\begin{array}{l}\text { How often do you use } \\
\text { radio as your } \\
\text { teaching aids }\end{array}$ & 100 & 0 & 0 & 0 & 0 \\
\hline 14 & $\begin{array}{l}\text { How often do you use } \\
\text { books as your } \\
\text { teaching aids }\end{array}$ & 0 & 0 & 0 & 17.65 & 82.35 \\
\hline 15 & $\begin{array}{l}\text { How often do you use } \\
\text { motion pictures as } \\
\text { your teaching aids }\end{array}$ & 0 & 88.24 & 11.76 & 0 & 0 \\
\hline & Average & 35.29 & 11.37 & 31.37 & 16.47 & 5.49 \\
\hline
\end{tabular}

The Table 1 above reveals the level of Rijalul Ghad Islamic School teachers' application of teaching aids in the classroom. In average, it shows that, 5,49\% of the respondents agreed that their teacher 'always' apply teaching aids in the classroom, while $16,47 \%$ said that their teacher 'often' apply it and $31,37 \%$ said that their teacher 'sometimes' apply teaching aids in the classroom. However, about $11,37 \%$ respondents said that their teacher rarely used it while 35,29\% said that their teacher never used teaching aids in the classroom.

The finding during semi-structured interview reveals that the application of these instructional media in the classroom carried positive impact to the students, as well as to the teachers. The students got excited and they enjoyed their classroom interaction process. They also had fun, especially during the making of instructional media with their friends and teachers. They also got happy during the application of animate teaching media (i.e. singing and pointing to their body parts). However, when comes to the question about the level of the application of the media, the teachers' responses were in the average position. This means that, the teachers were seldom applied or utilized waste materials as a medium of their teaching and learning instruction.

\section{DISCUSSION}

The results of the present study are based on the three types of data collection, they are: classroom observation and semi-structured interview with the teachers as well as the students as the respondents. The research results of this study are also gathered by a list 15item of questions (a questionnaire) about the level of application in utilizing instructional media by the teachers. This question was addressed to the teachers and the students.

The main purpose on the application of instructional media during classroom interaction is to promote effective learning in which by improving the quality of teaching 
and learning (Okobia, 2011).The waste materials used by the teachers as their instructional media were mostly made available by only the teachers while some were made by teachers and in collaboration with the students. These teaching aids were made of papers, plastic bottles (mineral water bottles).

The teaching aid made from paper was on the topic about family tree. This is done because concepts and abstracts or ideas will be easily transferred as they act as supporting elements in classroom interactions (Yildirim, 2008). The process was: first, the teachers prepared some blank paper sheets and distributed to the students. After that, the teachers drew two big circles indicating parents (father and mother) in the blank paper. After that, they made a line to connect the two circles. The line indicated relationship between the two circles. After that, they continued to draw two small circles (indicating children) under the two big circles. And then, they drew lines to make connection between those lines. After finishing the drawing, the teachers wrote the names of their father and mother inside the big circles and write their own names inside the first small circle and their brother's or sister's name inside the other small circle. After the teachers finished their drawing, they helped their students to make their own drawing. Color pencils were also applied in the circles. When all the students finished their drawing, they were asked to introduce their family members' name (e.g. parents and siblings) in English (e.g. This is my father. his name is Mr. Jordan Anderson, etc.). Hence, it is agreed that the importance on the application of instructional materials in classroom interaction as to achieve better performance of students in their academics (Nwike \& Catherine, 2013, Tuimur \& Chemwei, 2015; Okobia, 2011; Arum, 2015).

Regarding utilizing plastic mineral water bottles as a medium of instruction, the students were asked to make a project under the topic things in the sea. This topic was addressed because most of the students' parents are fishermen. In groups, the students were asked to make a small boat from used drinking water mineral bottles. First, the students were asked to collect any used drinking water mineral bottles found in their surroundings. After that, they brought to school and the teachers showed them how to make the boat. They were also asked to decorate the boat using flags and banner made from used papers. It was found that, during the process of making the boat, the students discussed and shares their thoughts among the group members. This discussion process was not only taught the students to finish their project, but also asked them to respect other's opinion as well as taught them to work in team (team work exercise). After finishing their project, they were asked to introduce their boat in English (e.g. this is my boat. Her name is Titanic, etc.). This is in line with Okobia (2011), as he points out that the use of classroom instructional aids or materials does not only help teachers and students to work collaboratively but also results in more cooperative learning activities among the students (Okobia, 2011).

When utilizing living things as instructional media, the teachers used themselves as their media of instructions. For example, when the topic was about parts of body, the teachers used a song (e.g. my head, my nose song) and they pointed or touched the parts of their body according to the words in the song lyric. The students showed a joyful feeling when they sang the song while pointing or touching the parts of their body. Study carried out have shown that instructional media help teachers to convey teaching and learning materials effectively as they assist students in greater acquisition of learning materials (Naz and Akbar, 2010). In addition, instructional media may also help to draw students' attention in the classroom learning process (Reeves, 1998). In addition, the work of 
Sampath (1990) implies that for more learning experiences to be internalized and achieved, more of the students' senses have to be stimulated. Various senses of the students need to be stimulating at once such as practicing (saying and doing) rather than theorizing (reading) alone.

\section{CONCLUSION}

The instructional media applied in the classroom can be utilized from waste materials such as paper, plastic bottles or from living things such as plants or humans. In general the application of instructional media in the classroom carries positive impact not only to the students, but also to the teachers. The following study reveals that the students became active and they enjoyed their classroom interaction process when instructional media applied. In addition, they also learn how to work in team and how to appreciate other's opinion during group discussion. However, a support on the use of teaching aids, especially teacher's made (or teacher-students' made) need to be increased among teachers. This is because, not all teachers are able to utilize waste materials in to instructional media.

\section{REFERENCES}

Alobo, J.O. (2010). Towards Selection of Instructional Media For Effective Teaching And Learning Of English As A Second Language In Secondary Schools. Journal of the Nigeria English Studies Association (JNESA). Vol. 13(2). pp. 106 - 116.

Arum, J.N. (2015). Availability And Utilization of Instructional Materials for The Implementation of The New Biology Curriculum In Senior Secondary Schools In Lagos, Nigeria. Sky Journal of Educational Research. Vol. 3(7), pp. 078 - 086.

Azikiwe, U. (2007). Language Teaching and Learning. Onitsha: Afiricana-First Pubs Ltd.

Brok, D. P., Levy. J., Brekelmans. M., \&Wubbels, T. (2005). The Effect of Teacher Interpersonal Behaviour on Students' Subject-Specific Motivation. Journal of Classroom Interaction. Vol. 40(2). pp. 20 - 33.

Chandra, A., Shah, A \& Joshi, U. (1998). Fundamentals of Teaching Home Science. New Delhi: Sterling Publishers, Private Limited.

Damanhuri. E. (2005). Some Principal Issues on Municipal Solid Waste Management in Indonesia. Expert meeting on waste management in Asia-Pacific Islands, Tokyo.

Damanhuri. E. (2010). Informal Collectors of Recyclable Waste and Used Goods in Indonesia. ERIA Research Project Report, No. 10. 3r Policies for East Asia. pp. 71 $-101$.

Gagne, R.M., Briggs. L.J., \& Wager. W.W. (1992). Principles of Instructional Design $4^{\text {th }}$ Edition. Ted Buchholz. USA.

Hamre, B. K., \&Pianta, R. C. (2001). Early Teacher-Child Relationships and The Trajectory of Children's School Outcomes Through Eighth Grade. Child Development. Vol. 72(2). pp. 625-638. 
Hancock. B., Ockleford. E., Windridge. K. (2007). An Introduction to Qualitative Research. The NIHR RDS EM / YH.

Kemp, J. E. \&Daylon, D. K. (1998). Planning and Producing Instructional Media. New York: Harper \& Row Publishers.

Kochhar, S.K. (2004). Methods and Techniques of Teaching. New Delhi: Sterling

Leoanak, S. P. P., \&Amalo, B. K. (2018a). Teachers' Beliefs and Perceptions of Code Switching in English as Foreign Language Classroom. In SHS Web of Conferences (Vol. 42, p. 00034). EDP Sciences.

Leoanak, S. P. P., \&Amalo, B. K. (2018b). Teacher's behaviour towards students' motivation practice. In SHS Web of Conferences (Vol. 42, p.78). EDP Sciences.

Makewa, L.N, Role. E, Ngussa. B. (2012). Usefulness of Media Resources in English Instruction: A Case of Adventist Secondary Schools in Tanzania. J. Educ. Pract.Vol. 3(15). pp. 163 - 172.

Manjale, N.B., \& Abel. C. (2017). Significance and Adequacy of Instructional Media as Perceived by Primary School Pupils and Teachers in Kinondoni District, Tanzania. International Journal of Educational Policy Research and Review. Vol.4(6). pp. 151-157.

Mehra, V. (1992). Instructional System Design an Innovation in Educational Technology. Delhi: S. S. Publishers.

Mustapha, F. E. et al., (2002). Media Methods in Instruction: An Education Technology Approach. Kano: Rainbow Royale Publishers.

Naz, A.A., \&Akbar. R.A. (2010). Use of Media for Effective Instruction its Importance: Some Consideration. Journal of Elementary Education A Publication of Deptt. of Elementary Education IER, University of the Punjab, Lahore - Pakistan. Vol. 18(12). pp. $35-40$.

Newby, T.J., Stepich, D.A., Lehman, J.D. \& Russell, J.D. (2000). Instructional technology for teaching and learning: Designing instruction, integrating computers, and using media. (2nd ed.). Upper Saddle River, NJ, Merrill.

Nicola, H., \& Nicola, B. (1997). How to Make and Use Visual Aids. London: Heinemann.

Nwike, M.C., \& Catherine. O. (2013). Effects of Use of Instructional Materials on Students Cognitive Achievement in Agricultural Science. Journal of Educational and Social Research. Vol. 3 (5). pp. 103 - 107.

Okobia, E.O. (2011). Availability and Teachers' Use of Instructional Materials and Resources in the Implementation of Social Studies in Junior Secondary Schools in Edo State Nigeria. Review of European Studies. Vol. 3(2). pp. 90 - 97.

Olawale, S. K. (2013). The use of instructional materials for effective learning of Islamic studies. Journal of Jihat al-Islam. Vol. 6(2). pp. $29-40$.

Omenge, O.R., \& Priscah. M.J. (2016). Understanding the Utilization of Instructional Media in Training Health Professionals. Journal of Nursing and Health Science (IOSR-JNHS) Vol. 5(3) Ver. III. pp. $01-08$. 
Patton, M.Q., \&Cochran. M. (2002). A guide to using qualitative research methodology. Médecins Sans Frontières, Paris. h

Reeves, T.C (1998). The impact of media and technology in schools. J. Art and Design Educ. 2. pp. $58-63$.

Sampath, K., (1990). Introduction to educational technology. New Delhi: Sterling Publishers. Private Limited.

Tuimur, H.N., \&Chemwei. B. (2015). Availability and use of instructional materials in the teaching of conflict and conflict resolution in primary schools in Nandi North District, Kenya. International Journal of Education and Practice. Vol. 3(6). pp. 224 $-234$.

Vagias, W.M. (2006). Likert type scale response anchors. Clemson International Institute for tourism \& research development, Department of Parks, Recreation and Tourism Management. Clemson.

Yeboah, R., Asante. E.A., \&Asare, N.A.O. (2016). Teaching Interactive Art Lessons with Recycled Waste Materials as Instructional Resources. Journal of Education and Practice. Vol.7(14). pp. $38-59$.

Yildrim, K. (2008). A Case Study on the Use of Materials by Classroom Teachers. Educational Sciences: Theory \& Practice. Vol. 8 (1). pp. $305-322$. 